CONSTITUTIONAL LAW: GIRGUIT COURT DETERMINES

\title{
A RELATIONSHIP BETWEEN FIRST AND FIFTH AMENDMENTS IN CONTEXT OF ORGANIZATIONAL DISCLOSURE
}

\begin{abstract}
Negating the Communist Party's statutory obligation to 'disclose information inculpatory to its members on the basis of the fifth amendment privilege against self-incrimination, the Court of $A p$ peals for the District of Columbia Circuit adopted a theory of fifth amendment applicability for first amendment groups. An examination of fifth amendment policies supporting this result provides a rationale for granting protection against compelled self-incrimination to all individuals in organizational roles.
\end{abstract}

W

HILE the fifth amendment privilege against self-incrimination has long prohibited the compelled production or inspection of an individual's private incriminatory papers, ${ }^{1}$ a concomitant line of authority has exorcised organizational records from the protective ambit of that privilege. ${ }^{2}$ Considering such collectivized informa-

${ }^{1}$ See, e.g., Gouled v. United States, 255 U.S. 298, 309.13 (1921); Boyd v. United States, 116 U.S. 616, 630-35 (1886); Takahashi v. United States, 143 F.2d 118, 123-25 (9th Cir. 1944); United States v. Wong Quong Wong, 94 F. 832 (D. Vt. 1899); J. Maguire, Evidence of GuILT $\$ 2.04$, at 22-24 (1959) [hereinafter cited as MAGuire]; $8 \mathrm{~J}$. Wigmore, EvideNcE $\S \S 2200,2264$ (McNaughten rev. ed. 1961) [hereinafter cited as WIGMORE]; Corwin, The Supreme Court's Construction of the Self-Incrimination Clause, 29 Micr. L. REv. 1, 15-19 (1930); Morgan, The Privilege Against Self-Incrimination, 34 MiNN. L. REv. 1, 34-38 (1949); Note, Evidentiary Searches: The Rule and the Reason, 54 GEo. L.J. 593, 596-600, 622-28 (1966); cf. United States v. Stern, 225 F. Supp. 187, 189.95 (S.D.N.Y. 1964). But see Abel v. United States, 362 U.S. 217, 234-41 (1960); United States v. Boyette, 299 F.2d 92, 95-96 (4th Cir.), cert. denied, 369 U.S. 844 (1962); United States v. Fulcher, 229 F. Supp. 456, 458 (D. Md. 1964); cf. Rogers v. United States, 340 U.S. 367, 371-72 (1951).

It seems likely that the overruling of the mere evidence rule in Warden v. Hayden, 387 U.S. 294, 300-10 (1967), will render private papers subject to inspection under the fourth amendment, although an individual himself may still not be compelled to produce them in court because of the fifth amendment. Compare Warden v. Hayden, supra, with Schmerber v. California, 384 U.S. 757, 760-64 (1966), and Note, Supreme Court Delineates the Relationship Between the Fourth and Fifth Amendments, 1967 DURe L.J. 366, 384 \& n.106. But see Note, Evidentiary Searches: The Rule and the Reason, 54 GEo. L.J. 593, 623-25 (1966).

3 See, e.g., Rogers v. United States, 340 U.S. 367, $371-72$ (1951); United States v. Morton Salt Co., 338 U.S. 632, 651-52 (1950); Oklahoma Press Publishing Co. v. Walling, 327 U.S. 186, 205-10 (1946); United States v. White, 322 U.S. 694, $697-705$ (1944); United States v. Bausch \& Lomb Optical Co., 321 U.S. 707, 726-28 (1944); Essgee Co. of China v. United States, 262 U.S. 151, 155-58 (1923); Wilson v. United States, 221 U.S. 361, 38186 (1911); Hale v. Henkel, 201 U.S. 43, 69-77 (1906); United States v. Onassis, 133 F. Supp. 327, 331-35 (S.D.N.Y. 1955); cf. Shapiro v. United States, 335 U.S. 1 (1948); Davis v. United States, 328 U.S. 582 (1946). But see United States v. Silverstein, 314 
tion to be impersonal in character, the courts have held that neither an organization nor its officers may invoke the privilege to prevent the production of records leading to the criminal prosecution of either. ${ }^{3}$ Further, an individual operating within the organizational framework may be required both to record and produce self-incriminatory information of specified associational activities without recourse to the fifth amendment. ${ }^{4}$ Because disclosure has been considered necessary to organizational regulation, 5 ensuing personal incrimination has been regarded as a justifiable consequence. ${ }^{6}$

F.2d 789 (2d Cir.), cert. denied, 374 U.S. 807 (1963); United States v. Cogan, 257 F. Supp. 170 (S.D.N.Y. 1966); cf. In re Subpoena Duces Tecum, 81 F. Supp. 418 (N.D. Cal. 1948). See also New York ex rel. Bryant v. Zimmerman, 278 U.S. 63 (1928).

${ }^{3}$ See cases cited note 2 supra; notes 5, 6 infra and accompanying text. See generallly 8 WIGMORE $\$ \S 2259$ a-d; Corwin, supra note 1, at 16-19.

"Under the so-called "required records" doctrine promulgated by Shapiro v. United States, 335 U.S. 1 (1948), the Government may require the production of information generally attendant to subjects of appropriate governmental regulation. Cf. United States v. Sullivan, 274 U.S. 259 (1927); FTC v. National Biscuit Co., 18 F. Supp. 667 (S.D.N.Y. 1937); notes $47-49$ infra. However, the Government may also demand reports for the additional purpose of securing evidence of criminal violations of regulatory laws. See Shapiro v. United States, supra at 15; note 49 infra and accompanyiug text. See generally Mansfield, The Albertson Case: Conflict Between the Privilege Against Self-Incrimination and the Government's Need for Information, 1966 Sur. CT. REv. 103; Meltzer, Required Records, The McCarran Act, and the Privilege Against Self-Incrimination, 18 U. CHI. L. REv. 687 (1951); Note, 65 Colum. L. REv. 681 (1965); Note, The Constitutional Rights of Associations to Assert the Privilege Against Self-Incrimination, 112 U. PA. L. REv. 394 (1964). However, the Court's recent extension of fifth amendment scope to include products of testimonial compulsion may foreclose the compelled personal disclosure of incriminatory information in associational records. Compare Schmerber v. California, 384 U.S. 757, 763-64 (1966), with Gilbert v. California, 388 U.S. 263, 266-67 (1967).

- See, e.g., United States v. Morton Salt Co., 338 U.S. 632, 651-53 (1950); United States v. Bausch \& Lomb Optical Co., 321 U.S. 707, 724-28 (1944); ICC v. Baird, 194 U.S. 25, 44-47 (1904); cf. ICG v. Brimson, 154 U.S. 447, 473-75 (1894); 8 W1GMore \$ 2259c, at 367; Meltzer, supra note 4, at 727-28.

- The self-incrimination of individual officers has been masked by various theories of waiver, license, and property rights. The property theory states that since party $A$ has no privilege with respect to the incriminatory records belonging to party $B$, the corporate officer cannot invoke the privilege with respect to the corporation's records. See, e.g., Johnson v. United States, 228 U.S. 457, 458 (1913); Hale v. Henkel, 201 U.S. 43, 70 (1906); Meltzer, supra note 4, at 705-08; Note, The Constitutional Rights of Associations to Assert the Privilege Against Self-Incrimination, 112 U. PA. L. REv. 394, 396, 406-07 (1964). Under the so-called licensing theory, the individual has no privilege because he has chosen to engage in an activity which is subject to governmental approval or control and is therefore subject to regulation through informational reports. See Morgan, supra note 1, at 36-38; cf. Shapiro v. United States, 335 U.S. 1, 32, 35 (1948). The waiver theory promulgated in Wilson v. United States, 221 U.S. 361, 380-85 (1911), assumes that by simply becoming responsible for corporate records or activity, an officer thereby waives the privilege against self-incrimination with respect to corporate information. See note 36 infra and accompanying text. See generally 8 Wigmore $\$ \S 2259 \mathrm{a}-\mathrm{d}$; Meltzer, supra note 4, at 702-08, 713-15. 
Recently, the Court of Appeals for the District of Columbia Circuit circumscribed this line of authority by holding the privilege available to associations which are repositories of their adherents' first amendment rights-if disclosure of the records would result in criminal prosecution of the membership. ${ }^{7}$

Communist Party of the United States v. United States (1967) ${ }^{8}$ eviscerates the Subversive Activity Control Board's (SACB) longstanding order that the Communist Party register as a "communist action" organization. ${ }^{9}$ That directive not only required the Party so to register, but also commanded its officers to file an accompanying statement containing the Party's membership lists. ${ }^{10}$ The Supreme

7 Communist Party of the United States v. United States, 384 F.2d 957 (D.C. Cir. 1967). The concurring opinion was based upon the concept that each member of the Party had access to the privilege against self-incrimination. Thus, group disclosure which could be accomplished only through such members could not be compelled under threat of punishment. Id. at 968-69 (concurring opinion). See notes 99-101 infra and accompanying text.

s 384 F.2d 957 (D.C. Cir. 1967).

- The legislative order, from initial investigation to the decision in the instant case, represents approximately 17 years of Board proceedings and court litigation. In 1950 the Attorney General petitioned the Board to order the Party's registration pursuant to $\$ 13(\mathrm{a})$ of the Subversive Activities Control Act of 1950, 50 U.S.C. $\$ 792$ (a) (1964). The Party uusuccessfully sought a stay of proceedings on the ground that such hearings would violate the first and fifth amendments. Communist Party of the United States v. McGrath, 96 F. Supp. 47 (D.D.C.), stay pending appeal denied, 340 U.S. 950 (1951). After voluminous hearings, the Board determined that the Party was a "communist action" organization and issued a registration order to that effect. The Party appealed that determination, attacking the constitutionality of both the Act and the Board's order as well as the evidentiary basis of the order. The District of Columbia Circuit upheld the Board order denying appellant's motion to adduce new evidence. Communist Party of the United States v. SACB, 223 F.2d 531 (D.C. Cir. 1954). However, the Supreme Court reversed and remanded to the Board for determinations based upon untainted evidence. Communist Party of the United States v. SACB, 351 U.S. 115 (1956). The Board affirmed its original order and the Circuit Court reversed on the basis that the Party had been improperly denied discovery of governmental documents. Communist Party of the United States v. SACB, 254 F.2d 314 (D.C. Cir. 1958). Upon second remand, the Board reconfirmed its determination that appellant was a "communist action" group and issued yet another registration order. The District of Columbia Circuit affrmed that directive. Communist Party of the United States v. SACB, 277 F.2d 78 (D.C. Cir. 1959). On appeal, the Supreme Court sustaincd the validity of the registraiton order but declined to reach the question of compelled self-incrimination. Communist Party of the United States v. SACB, 367 U.S. 1 (1961). When the Party refused to register, it was convicted of failure to comply with the Board order. However, that judgment was overturned on the basis of the Party's argument that it could not register without incriminating its members. Communist Party of the United States v. United States, 331 F.2d 807 (D.C. Cir. 1963), cert. denied, 377 U.S. 968 (1964). At the second trial, the Party maintained its fifth amendment stance, arguing that disclosure by any member to any person would result in selfincrimination. The instant case is an appeal from the second conviction. Communist Party of the United States v. United States, 384 F.2d 957 (D.C. Gir. 1967).

${ }^{10}$ Section $3(3)$ of the Subversive Activities Control Act of 1950, 50 U.S.C. $\$ 782$ (3) (a) 
Court upheld the disclosure requirements as a legitimate restriction upon the first amendment privileges of anonymity and association ${ }^{11}$ on the basis of congressional findings that the Party had taken action preparatory to violent overthrow of the Government. ${ }^{12}$ The Court ruled that assertion of the fifth amendment privilege against selfincrimination was not ripe for adjudication because no proceedings had been instituted to punish the Party or its officers for failure to comply with the challenged directive. ${ }^{13}$ However, in a decision

(1964), defined a "communist-action" group as "any organization . . . which (i) is substantially directed, dominated, or controlled by [the Soviet Union] . . . and (ii) operates primarily to advance the objectives of such world Communist movement ...." Under $\S 13$ (a) of that Act, 50 U.S.C. $\$ 792$ (a) (1964), the Attorney General was directed to petition the Board for an order requiring the registration of any "communist-action" organization which had not reported as such within thirty days after the Act became effective. Following a Board determination of "communist-action" status, $\$ 7$ (a) of the Act, id. $\$ 786(\mathrm{a})$, required the affected organization to register with the Attorney General "on a form prescribed by him by regulations . . .." Section 7 (d), id. $\$ 786$ (d), required, inter alia, that the accompanying registration statement contain the name of the organization and the address of its principal office; the names and addresses of its present officers and of individuals who have been officers within the preceding twelve months, with a designation of the office held by each and a brief statement of the functions and duties of each; an accounting of all moneys received and expended by the organization during the past twelve months; and the name and address of each individual who was a member during the preceding twelve months.

${ }_{11}$ Communist Party of the United States v. SACB, 367 U.S. 1 (1961).

12 Id. at 88-105.

${ }^{13}$ The Party had attempted to raise the privilege on behalf of its officers, arguing that requiring their personal signatures pursuant to 28 C.F.R. $\$ \S 11.200,11.205$ (Supp. $1960)$ would subject them to self-incrimination. The majority opinion evaded the issue by contending that since the order was not yet final, "[w]e cannot know now that the Party's officers will ever claim the privilege," or whether the Attorney General would honor the privilege if claimed. 367 U.S. at 107. Four Justices dissented from that position arguing that the disclosure provisions came into direct conflict with the privilege against self-incrimination. Mr. Justice Black argued that the penalties visited upon members under the Smith Act, 18 U.S.C. $\$ 2385$ (1964), and the Subversive Activities Control Act, 50 U.S.C. $\$ \$ 781-98$ (1964), were sufficient to raise the privilege as a shield against the officers' self-incrimination through registration. 367 U.S. at 137-45 (Black, J., dissenting). Mr. Justice Douglas, while agreeing with Mr. Justice Black that the statute violated the fifth amendment because of its incriminatory effect upon individual members, see $i d$. at 175-84 (Douglas, J., dissenting), also raised a jus tertii argument based upon the "intimate connection between associations and their members." Id. at 184-88. In his view, the Party could assert the privilege to avoid the Act's inevitable effect of depriving members of their privilege against being "compelled to reveal their connection with the Party." Id. at 187 . Mr. Justice Brennan, joined by the Chief Justice, dissented in part, contending that the Court should reach the particular issue of whether the registration requirements violated the fifth amendment privilege of the officials charged with registering the Party. Id. at 192-93 (Brennau, J., dissenting in part). Mr. Justice Brennan noted that forcing an individual to claim the privilege in lieu of signing a registration statement, on the basis that he was an officer to whom the order applied, was itself self-incrimination. Thus, the statute unconstitutionally demanded an incriminatory response to an "indirect" inquiry. Id. at 195-96; see Byse, Teachers and the Fifth Amendment, 102 U. PA. L. REv. 871, 
rendered the same day, ${ }^{14}$ the Court affirmed the criminal conviction of a Communist Party adherent under the "membership" clause of the Smith Act.15 Consequently, it became clear that disclosure of Party membership lists might subject all members to criminal prosecution, particularly those officers signing the disclosure statement itself.

Subsequent to these decisions, regulations were promulgated which permitted the Party to register and disclose through any willing "agent" or "other person" rather than through officers or members. ${ }^{16}$ The Party, however, declined to authorize disclosure by any agent and asserted the privilege against self-incrimination on behalf of its officers and members. ${ }^{17}$ Rejecting this claim, the Government initiated successful proceedings against the organiza-

876 (1954); McNaughton, The Privilege Against Self-Incrimination, 51 J. CrIM. L.C. \& P.S. 138, 152-53 \& n.61 (1960); Ratner, Consequences of Exercising the Privilege Against Self-Incrimination, 24 U. CHI. L. REv. 472, 490 (1957). In his opinion, the registration requirement was particularly offensive because it forced the individual Party member to come forward and claim the privilege although the Government had not satisfied an initial burden of inquiry by naming the official as a probable source of relevant evidence. 367 U.S. at 196 (Brennan, J., dissenting in part); cf. McNaughton, supra, at 145-46 \& n.37, 153-54. Further, Mr. Justice Brennan stated that he failed to see the distinction between the oral testimony protected by Curcio v. United States, 354 U.S. 118 (1957), and the "written testimony" of signing the registration statement. 367 U.S. at 201 (Brennan, J., dissenting in part). In his view, both were equally entitled to fifth amendment protection.

14 Scales v. United States, 367 U.S. 203 (1961); cf. Noto v. United States, 367 U.S. 2,90 (1961).

${ }^{25} 18$ U.S.C. $\$ 2385$ (1964). The provision states that: "Whocver organizes or helps or attempts to organize any society, group, or assembly of persons who teach, advocate or encourage the overthrow or destruction of any such government by force or violence; or becomes or is a member of, or affiliates with, any such society, group, or assembly of persons, knowing the purposes thereof-

Shall be fined ... or imprisoned ... or both ...." (emphasis added).

${ }_{18}$ The previous regulations, in force at the time of Communist Party of the United States v. SACB, 367 U.S. I (1961), required the disclosure statement to be signed by the "partners, officers, directors and members of the governing body." Form ISA-1, 28 C.F.R. $\$ 11.200$ (Supp. 1960). Perhaps because of the strong dissents by members of the Court in 1961, the regulations were changed to allow registration by any willing "agent or other person." Forms IS.5I (a) (registration) and IS-51 (disclosure), 28 C.F.R. $\$ \S 11.200-.207$ (1966); see Communist Party v. United States, 384 F.2d 957, 959 n.2 (D.C. Cir. 1967); note 10 supra.

${ }_{13}$ The extent of the Party's compliance with the registration order was limited to notfying the Justice Department, on official Party stationery, that its officers declined to authorize disclosure of information other than the organization's name, address, and telephone number because of the fifth amendment privilege against self-incrimination. 384 F.2d at 967. This letter, signed by the "authorized officers" of the Party, also challenged the Government's right to compel the Party to characterize itself as dom. inated by the Soviet Union when the Party itself did not believe the organization to bc so controlled. Brief for Appellant at 15. See note 69 infra and accompanying text. 
tion for failure to register. This conviction was reversed and remanded by the District of Columbia Circuit ${ }^{18}$ which relied upon the criminality connected with Party membership to conclude that: (1) the self-incrimination privilege was available to the officers of the Party, (2) that privilege had in fact been adequately asserted, (3) to the extent registration could, under the regulations, be effected by an "agent" or "other person," conviction must at least rest upon proof of the availability of such person. ${ }^{19}$

Seeking to meet this last requirement, and thus vitiate the association's claim of privilege, the Government produced two informer-members at the Party's second trial who testified that they were willing to register appellant and disclose the necessary information when, and if, it was made available by the Party. ${ }^{20}$ Conviction and the instant appeal followed. In Communist Party of the United States $v$. United States $(1967)^{21}$ the District of Columbia Circuit overruled the conviction of the Party for failure to comply with the registration order. Since the criminal status of knowing Party membership had previously been held constitutional, ${ }^{22}$ the court found the statutory scheme compelling the Party to disclose its membership prohibited by the "privilege against incrimination." 23

${ }^{18}$ Communist Party of the United States v. United States, 331 F.2d 807, 811-13 (D.C. Cir. 1963), cert. denied, 377 U.S. 968 (1964). The court's rationale was that the mere act of registering for the Party was self-incriminatory, a situation to be contrasted to the potential incrimination resulting from the production of subpoened inculpatory organizational records. Id. at 812-13. But see Boyd v. United States, 116 U.S. 616, 63137 (1886); note 74 infra; cf. Wilson v. United States, 221 U.S. 361, 377-80 (1911).

10 Communist Party of the United States v. United States, 331 F.2d 807, 812-15 (D.C. Cir. 1963), cert. denied, 377 U.S. 968 (1964); see Communist Party of the United States v. United States, 384 F.2d 957 (D.C. Cir. 1967). The statement that the Government must prove the availability of a willing witness was predicated upon earlier cases which allowed the disclosure of incriminatory material only through such a voluntary agent. See 331 F.2d at 814-15; cf. United States v. 3963 Bottles, 265 F.2d 332, 336 (7th Gir.), cert. denied, 360 U.S. 931 (1959); United States v. 42 Jars, 162 F. Supp. 944 (D.N.J. 1958); Simon v. American Tobacco Co., 192 F. 662 (C.C.S.D.N.Y. 1942). See also McPhaul v. United States, 364 U.S. 372 (1960); United States v. Fleischman, 339 U.S. 349, 356-65 (1950); Morrison v. California, 291 U.S. 82, 88-91 (1934).

20384 F.2d at 967.

22384 F.2d 957 (D.C. Cir. 1967).

22 Scales v. United States, 367 U.S. 203 (1961); see notes 14 \& 15 supra and accompanying text; cf. Noto v. United States, 367 U.S. 290 (1961).

23 Apparently, the court deliberately dropped the "self" from the privilege against self-incrimination, in support of its theory that organizations of individuals asserting first amendment rights-"first amendment groups"-were themselves entitled to a privilege against self-incrimination. See 384 F.2d at 958 . This theory, however, fails on the facts of the case. See notes 103-07 infra and accompanying text. 


\section{The "Organization Man" and the Fifth Amendment}

The Supreme Court's expansive interpretation of the fifth amendment privilege against self-incrimination has rendered it applicable to individuals appearing either to testify or produce private papers before grand juries, legislative, quasi-judicial, and administrative bodies, and in police interrogations. ${ }^{24}$ Nevertheless, while expanding the scope of the fifth amendment for the "private" individual, the Supreme Court has generally denied the privilege with respect to organizations and has provided their officers with but limited protection from incrimination ${ }^{25}$ particularly within the context of economic regulation. ${ }^{26}$

\footnotetext{
${ }^{24}$ Miranda v. Arizona, 384 U.S. 436 (1966) (police interrogation); Murphy v. Watcrfront Comm'n, 378 U.S. 52 (1964) (bi-state regulatory and investigative commission); Malloy v. Hogan, 378 U.S. 1 (1964) (state court referee); Quinn v. United States, 349 U.S. 155 (1955) (congressional committee); McCarthy v. Arndstein, 266 U.S. 34 (1924) (bankruptcy proceedings); Counselman v. Hitchcock, 142 U.S. 547 (1892) (grand jury). The courts have further held that the privilege is properly invoked so long as the desired disclosure would provide a "link in the chain of evidence" leading to the criminal conviction of the protesting party. See, e.g., Counselman v. Hitchcock, supra at $574-75$.

${ }^{25}$ See cases cited notes 2 \& 4 supra. Commentators considering the problems of incriminatory group disclosures have generally criticized the enabling legislative schemes on the ground that the waiver, licensing, and property concepts fail to provide a rational constitutional basis for the resultant incrimination. See MAGUIRE $\$ \S 2.09$ (2)- (3); 8 WrGmoRe $\$ \$ 2259 \mathrm{~b} \cdot c$; Mansfield, supra note 4, at 116, 130-45; Meltzer, supra note 4, at 702-03, 706-15; Note, 65 Colum. L. Rev. 681, 685-87 (1965); Note, 68 HARv. L. Rev. 340, 341-45 (1954); Note, The Constitutional Rights of Associations to Assert the Privilege Against Self-Incrimination, 112 U. PA. L. Rev. 394, 400.03 (1964); cf. Rice, The Constitutional Right of Association, 16 HAstincs L.J. 491, 492, 503.08 (1965). But see Davis, The Administrative Power of Investigation, 56 YALE L.J. $1111,1127-29$ (1947). See also Fraser, The Privilege Against Self-Incrimination As Applied to Custodians of Organizational Records, 33 WASH. L. REv. 435 (1958). However, many of the same authorities have approved the "public interest" concept as a sufficient constitutional ground for eliminating the privilege for individual members of an organization. See MAGUIRE $\S 2.09$, at 105; 8 WrGMORE $\$ 2259$ c, at 367 ; Mansfield, supra note 4, at 119 ; Meltzer, supra note 4, at 727-28; Note, 65 Colum. L. Rev. 681, 682-83, 695 (1965); Note, 68 HARv. L. Rev. 340, 344-46 (1954). But cf. Douglas, The Right of Association, 63 Colum. L. Rev. 1361 (1963). Most have considered due process protections sufficiently broad to prevent abuse of disclosure procedures. See note 82 infra.

${ }^{20}$ Despite the inapplicability of the fifth amendment to corporations and other organizations, the fourth amendment's protection against unreasonable searches and seizures has been extended to these groups. See, e.g., Go-Bart Importing Co. v. United States, 282 U.S. 344 (1931); Silverthorne Lumber Co. v. United States, 251 U.S. 385 (1920); Hale v. Henkel, 201 U.S. 43, 76 (1906). However, broad congressional grants of administrative power also have served effectively to dilute this privilege on the theory that there is less reason to protect corporate privacy than that of the individual. See, e.g., United States v. Morton Salt Co., 338 U.S. 632, 651-53 (1950); Hale v. Henkel, supra at 82-83 (McKenna, J., concurring); cf. Shapiro v. United States, 385 U.S. 1, $29-33$ (1948); Davis v. United States, 328 U.S. 582, 588-93 (1946). See generally Davis, supra note 25; Rogge, Inquisitions by Officials: A Study of Due Process Require-
} 
In the first significant case considering the constitutional implications of compelled production of organizational records, Boyd $v$. United States, ${ }^{27}$ the Supreme Court determined that the privilege prohibited coerced self-incrimination in the form of response to a subpoena duces tecum of "private" business papers. ${ }^{28}$ While the Boyd rationale equated compelled production with coerced testimony, ${ }^{29}$ the privilege apparently depended upon whether the records were required to be kept by law, and were therefore open to public inspection, rather than upon a categorization of "personal" versus "business" records. ${ }^{30}$ The public inspection distinction, however,

ments in Administrative Investigations (pts. I-III), 47 MINN. L. REv. 939 (1963), 48 MINN. L. Rev. 557, 1081 (1964); Note, Discovery in Federal Administrative Proceedings, 16 STAN. L. REv. 1035 (1964).

Recently, in United States ex rel. DeForte v. Mancusi, 379 F.2d 897 (2d Cir. 1967), the Second Circuit ruled that an indicted officer had standing to challenge the admission of evidence resulting from an illegal search and seizure of his union's Iecords where the search was directed at him and was an invasion of his privacy. Id. at 903-05; cf. See v. Seattle, 387 U.S. 541 (1967); Jones v. United States, 362 U.S. 257 (1960). But cf. Meltzer, supra note 4, at 693-94. While the decision provides greater protection for the accused in an explicitly criminal case, it seems unlikely to carry over as precedent in an administrative hearing conducted prior to prosecutorial activity. See United States v. Morton Salt Co., 338 U.S. 632, 640-43 (1950); Meltzer, supra note 4, at 701. But see Note, 68 HARv. L. REv. 340, $346-49$ (1954). See generally Handler, The Constitutionality of Investigations by the Federal Trade Commission (pts. I \& II), 28 CoLUM. L. Rev. 708, 905 (1928).

27116 U.S. 616 (1886).

${ }^{28}$ The Boyd Court's conception of "private" business papers seemed rather broad, apparently encompassing all records except "books required by law to be kept for ... inspection." Id. at 623-24.

${ }^{20}$ Id, at 633-37. See also Meltzer, supra note 4, at 721-23. The Boyd decision Ietains its validity with respect to the unconstitutionality of compelling the selfproduction of an individual's "private papers" to the present day. See Schmerber v. California, 384 U.S. 757, 763-64 (1966) (dictum); note I supra.

${ }^{30} \mathrm{I} 16$ U.S. at $622-23$. The Boyd Court's determination that the privilege was inapplicable only to "public" records required to be kept for public use comported with English doctrine allowing organizations and business enterprises of a "private nature" to retain the privilege against self-incrimination. See Rex v. Purnell, 96 Eng. Rep. 20 (K.B. 1748); Rex v. Cornelius, 93 Eng. Rep. I133 (K.B. 1744); Regina v. Mead, 92 Eng. Rep. 119 (K.B. 1703); Rex v. Worsenham, 91 Eng. Rep. 1370 (K.B. 1701). See also Wilson v. United States, 221 U.S. 361, 388-91 (191I) (McKenna, J., dissenting); Meltzer, supra note 4, at 702. The English privilege seemingly continues to the present day, where claimed by the company with respect to the demanded material. Cf. Triplex Safety Glass Co. v. Lancegaye Safety Glass, Ltd., [1939] 2 K.B. 395.

A strong argument can be made that the American doctrine of the inviolability of "private" papers has been severely limited by recent Supreme Court decisions. As originally articulated in Entick v. Carrington, 95 Eng. Rep. 807, (K.B. 1765), that concept was set forth in terms of prohibiting general or warrantless searches. Boyd v. United States, 116 U.S. 616 (1886), transported Entick into the constitutional law of this country. There the Court enunciated a dual concept of fourth amendment constructive search and self-incrimination under the fifth amendment to hold that an individual could not be compelled to produce incriminatory "prviate" documents. 
was subsequently discarded through a shift in the pivotal emphasis from the character of the records sought to the nature of the entity retaining those records. ${ }^{31}$ Postulating that submission to "visitorial" inspection of corporate records was an adjunct of governmental consent to function in corporate form, ${ }^{32}$ the Court concluded that the "personal" nature of the privilege rendered it available only to "natural" individuals-not to organizations. ${ }^{33}$ Although those broad

Id. at 626-35. Subsequently, Adams v. New York, 192 U.S. 585 (1904), and Gouled v. United States, 255 U.S. 298 (1921), indicated that private papers were not inviolable as a source of evidence in all cases under the fourth amendment. However, the latter case promulgated the mere evidence rule-that a search for and seizure of anything except contraband, instrumentalities, and fruits of a crime violated the fifth as well as the fourth amendment. Id. at 308-11.

The rule seems to have been best honored in the breach, except where "private" papers were concerned. Compare Marron v. United States, 275 U.S. 192, 199 (1927), and United States v. Boyette, 299 F.2d 92, 94-95 (4th Cir.), cert. denied, 369 U.S. 844 (1962), with United States v. Lefkowitz, 285 U.S. 452, 464-66 (1932), Takahashi v. United States, 143 F.2d 118, 123-25 (9th Cir. 1944), and United States v. Stern, 225 F. Supp. 187, 190-95 (S.D.N.Y. 1964). See generally Comment, Eavesdropping Devices and the Fourth Amendment, 66 CoLum. L. REv. 355, 359-70 (1966); Note, Supreme Court Delineates the Relationship Between the Fourth and Fifth Amendments, 1967 DuKE L.J. 366, 378 \& nn.78-81; Note, Evidentiary Searches: The Rule and the Reason, 54 GEO. L.J. 593 (1966).

The Supreme Court's invalidation of the mere evidence rule in Warden v. Hayden, 387 U.S. 294 (1967), indicated that Boyd is still authority for the proposition that an individual may not be compelled to produce incriminatory personal papers in court. Even that statement, however, seems too narrow because the fifth amendment would prohibit compelling an accused to bring any incriminatory material into court. Thus the only question remaining is whether this rule should extend to protecting an individual from the compulsory production of organizational records. See notes 112-22 infra and accompanying text; cf. Note, The Constitutional Rights of Associations to Assert the Privilege Against Self-Incrimination, 112 U. PA. L. REv. 394, 405.06 (1964).

${ }^{31}$ Hale v. Henkel, 201 U.S. 43, 74-76 (1906). Although early cases tended to rely upon the visitorial inspection rationale for defeating a corporate or associational individual's claim of privilege, the underlying theory that organizational records were subject to inspection because of their "public" nature came to the fore in Shapiro v. United States, 335 U.S. 1 (1948). That case explicated the "required records" doctrine, holding that records required to be kept for regulatory purposes thereby became "public" and open to inspection for the purpose of enforcing the relevant regulation. Id. at 22-34; see Meltzer, supra note 4, at 708-15; Note, 65 CoLum. L. REv. 681, 685 (1965).

32 The commerce clause basis of federal informational schemes was early recognized as a valid basis for inspection pursuant to the enforcement of federal regulations. However, the scope of this federal power was deemed to be much narrower than the general "visitorial" power of the states. See Wilson v. United States, 221 U.S. 361, 38284 (1911); Hale v. Henkel, 201 U.S. 43, $72-76$ (1906). But see Handler, The Constitutionality of Investigations by the Federal Trade Commission (pt. II), 28 ColuM. L. REv. 905, 918-37 (1928). With the expansion of the scope of the commerce clause, however, it became clear that, if anything, the fcderal investigatory power equaled that of the states. See United States v. Morton Salt Co., 338 U.S. 632 (1050); Shapiro v. United States, 335 U.S. 1 (1948).

${ }^{38} 201$ U.S. at 74-75. Prior to the Hale case the privilege was generally considered 
holdings were predicated upon the existence of an immunity statute protecting an officer producing the demanded records from criminal prosecution, ${ }^{34}$ the Court eventually found compelled disclosure proper even where such immunity was unavailable. ${ }^{35}$ This development rested upon the previously subordinated ground that, as custodian of the corporate records, the officer had "voluntarily assumed a duty which overrides his claim of privilege." 38

applicable to corporations. See W. SUTHERLAND, Notes oN ConstrTution of THE UNITED States 627-28 (1904); 4 J. Wigmore, Evidence \$2259 (1st ed. 1904); note 30 supra.

34 General Appropriation Act of February 25, 1903, ch. 755, §1, 32 Stat. 854, 904, cited in the Hale case, 201 U.S. at 66; see Wilson v. United States, 221 U.S. 361, 390 (1911) (McKenna, J., dissenting); Ex Parte Chapman, 153 F. 371 (C.C.D. Idaho 1907). The Chapman court distinguished the Hale case on the ground that the defendant Chapman was utilizing his own privilege, not that of the corporation, in refusing to produce incriminatory records. $I d$. at 375 . Moreover, the court reasoned, there was no immunity statute available to the Chapman defendant as there had been in Hale. Id. at 375-77. For a recent discussion of federal immunity provisions currently in force see Comment, The Federal Witness Immunity Acts in Theory and Practice: Treading the Constitutional Tightrope, 72 YALE L.J. 1568 (1963).

35 Wilson v. United States, 221 U.S. 361 (1911). The Wilson Court specifically rejected the English cases allowing corporations and their officers to invoke the privilege against self-incrimination. Id. at 385-86. See note 30 supra.

Wilson, however, was based upon a very restricted set of circumstances which scarcely warranted the broad rule that all officers could be compelled to incriminate themselves through the production of corporate records. The directors of the corporation whose records were involved had passed a resolution ordering the president to produce the subpoenaed information before the investigating grand jury. Moreover, the grand jury sought the records solely for the purpose of incriminating the corporate officer on a charge of fraudulent use of the mails. $I d$. at 367-71. It is arguable that today due process considerations would prevent such a single-minded effort on the part of the Government to secure books solely for the purpose of incriminating an individual. Cf. United States ex rel. DeForte v. Mancusi, 379 F.2d 897 (2d Cir. 1967); Mansfield, supra note 4, at 105-11. However, because the indictments and investigations were rendered pursuant to the congressional power to regulate mail service, it seems more likely that Shapiro v. United States, 335 U.S. 1 (1948), would be controlling, and the evidence would be admissible. See Meltzer, supra note 4, at 693-95; notes 47 \& 49 infra and accompanying text. But see Note, 68 HARv. L. REv. 340, 346 (1954).

${ }^{30} 221$ U.S. at 380 . The consent or waiver rationale has been severely attacked by critics of the disclosure doctrine as begging the question of an individual's fifth amendment privilege in a group context. See Meltzer, supra note 4, at 703-04; note 6 supra. Mr. Justice McKenna, who dissented in Wilson, felt that the "waiver" rationale was viable only where one undertook to become the custodian of governmental "public" records. Only then, knowing that such records were open to general inspection, could an individual be said to have "waived" the privilege. See 221 U.S. at 388-90 (McKenna, J., dissenting); Note, 47 Colum. L. REv. 838 (1947); of. Shapiro v. United States, 335 U.S. 1, 65-68 (1948) (Frankfurter, J., dissenting). Mr. Justice McKenna also noted that property considerations had little to do with the assertion of a constitutional privilege. 221 U.S. at 387-88. His views were confirmed with respect to the fourth amendment in Jones v. United States, 362 U.S. 257, 265-67 (1960). See United States ex rel. DeForte v. Mancusi, 379 F.2d 897 (2d Cir. 1967). However, the "property" theory of fifth amendment applicability, i.e., that the privilege may not be utilized 
While the concept of visitorial powers ${ }^{37}$ first developed with the advent of official limitations on corporate activities, ${ }^{38}$ it subsequently became clear that disclosure was generally an exercise in the regulation of commerce and not simply supervision of the corporate form. ${ }^{30}$ In United States $v$. White, ${ }^{40}$ the Supreme Court recognized that since entities such as unions, religious bodies, or social groups are not subject to state approval for their existence, the "visitorial" inspection theory was too narrow to sustain the compelled disclosure of these organizations' records and the corresponding diminution of their officers' privilege against self-incrimination. ${ }^{41}$ Rather, emphasizing the "personal" nature of the privilege,42 the Court grounded the constitutionality of such informational schemes upon the character of the collectivized interests sought to be regulated. Thus, the test for determining fifth amendment applicability to an organization and its officers was

whether ... under all the circumstances . . . a particular type of organization has a character so impersonal in the scope of its membership and activities that it cannot be said to embody the purely

to prevent the production of incriminatory records not belonging to the accused, has never been overruled. See Meltzer, supra note 4, at 706-08; Note, The Constitutional Rights of Associations to Assert the Privilege Against Self-Incrimination, 112 U. PA. L. REv. 394, 396 (1964); cf. Curcio v. United States, 354 U.S. 118, 122-25 (1957); United States v. White, 322 U.S. 694, 699 (1944). But cf. Katz v. United States, 389 U.S. 397, 350 n.5, 351-52 (1967).

${ }^{87}$ Hale v. Henkel, 201 U.S. 43, 74-75 (1906). One commentator has noted that prior to the Hale decision, the states had not assumed the visitorial powers assertedly theirs and had allowed corporations to invoke the privilege against self-incrimination. Note, The Constitutional Rights of Associations to Assert the Privilege Against Self-Incrimination, 112 U. PA. L. Rev. 394, 396-97 \& nn.24-26 (1964); see note 32 supra.

${ }^{88}$ See, e.g., Wilson v. United States, 221 U.S. 361, 382 (1911); Hale v. Henkel, 201 U.S. $43,74-75$ (1906).

${ }^{80}$ See, e.g., Hale v. Henkel, 201 U.S. 43, 72-75 (1906); ICC v. Baird, 194 U.S. 25, 4I45 (1904). Compare FTC v. American Tobacco Co., 264 U.S. 298, 305 (1924), with United States v. Morton Salt Co., 338 U.S. 632, 647-51 (1950).

10322 U.S. 694 (1944).

1 Id. at $700-05$.

42 Id. at 700-01. Emphasis upon the "personal" nature of the privilege allowed the Court simply to parallel and enlarge the original explication of the rationale of Hale v. Henkel, 201 U.S. 43 (1906). Thus, if the organization were not "personal" in character neither the entity nor its officers could elaim the privilege. Moreover, the White Court retained the "visitorial" power concept in a modified form, stating that "[b]asically, the power to compel the production of the records of any organization, whether it be incorporated or not, arises out of the inberent and necessary power of the federal and state governments to enforce their laws ..." 322 U.S. at 700.01. Nevertheless, the test of organizational fifth amendment applicability was set forth in terms of the relationship between the group and individual-not the association and the governmental need for information. Id. at 701 . 
private or personal interests of its constituents, but rather to embody their common or group interests only. ${ }^{43}$

Under this standard, neither a union, as an impersonal conglomeration of economic interests, nor its representatives could claim the fifth amendment with respect to incriminatory union records, for there was "no element of personal privacy" to which the privilege could attach. ${ }^{44}$ Although no criteria or constitutional bases for classifying an organization as "personal" or "impersonal" were enunciated, the Court still had attempted to formulate a test of fifth amendment applicability in terms other than the Government's self-serving declaration of "overriding public interest." 45 Nevertheless, the Court later obviated the basic premise of the White standard by denying fifth amendment applicability to the most "personal" of all regulatory economic disclosures. ${ }^{46}$ Reverting to a strict "public necessity" rationale, the Court approved the compelled disclosure of an individual businessman's incriminating records which had been kept pursuant to law. ${ }^{47}$ Expeditiously ignor-

4322 U.S. at 701.

«Id. at 700.03. See notes 112-21 infra and accompanying text.

"See note 42 supra. One commentator has suggested that the "public" interest in organizational information bears an inverse relationship to the "personal" nature of that organization. Thus, there may be little conflict between personal assertion of the privilege and the governmental need for information. See Note, The Constitutional Rights of Associations to Assert the Privilege Against Self-Incrimination, 112 U. PA. L. Rev. 394, 398-99, 407 (1964); cf. Douglas, supra note 25, at 1377-79. But cf. McNaughton, supra note 13 , at $145-46 \&$ \& .37 .

Meltzer has criticized the "personal-impersonal" test as vague in that the Court failed to reveal what criteria should be utilized to determine if a group, and thus its officers, meet the standard necessary for invocation of the fifth amendment privilege. Meltzer, supra note 4, at 705. Furthermore, he has questioned whether the obvious factors of size, numbers, or time given by individuals to group activities are proper criteria for determination of a constitutional privilege since they provide no measure of the public's interest in disclosure and show no clear relation to the purpose of the privilege. Id. at 705.06; see Fraser, supra note 25, at 445. But see Note, The Constitutional Rights of Associations to Assert the Privilege Against Self-Incrimination, 112 U. PA. L. REv. 394, 399 (1964) (vindicating the White test on the basis of additional mechanical factors). For a discussion of Professor Meltzer's "balancing" solution see note 82 infra.

${ }^{6} B$ ut cf. United States v. Fleischman, 339 U.S. 349, 358 (1950) (supporting the White test in dictum as applicable to officer of a political organization).

${ }^{47}$ Shapiro v. United States, 335 U.S. 1 (1948). The appellant, Shapiro, had been convicted of violating the Emergency Price Control Act of 1942, ch. 26, 56 Stat. 23. While the opinion suggests that the decision was based partially upon the powers of Congress to enact programs in pursuit of the war power, 335 U.S. at 11-14, 32, the case has not been distinguished by courts or commentators on that basis. See Mansfield, supra note 4, at 148-50; Meltzer, supra note 4, at 710-15; Note, 65 Colum. L. REv. 681, 685 (1965); Note, 68 HARv. L. REv. 340, 341-42 (1954). But see Note, The Constitutional 
ing White, ${ }^{48}$ the Court thus accepted the informational technique as a method of criminal detection ${ }^{40}$ and acknowledged at least a limited congressional power to withdraw the privilege from an individual by enacting regulatory laws requiring records of a particular economic form or activity. 50

The Court, however, has indicated that at least one aspect of the fifth amendment privilege remains available to the organizational individual ${ }^{51}$ by ruling that a custodian of records could not be comRights of Associations to Assert the Privilege Against Self-Incrimination, 112 U. PA. L. REv. 394, 402 (1964). The position of the Shapiro majority in enuncinting the "required records" doctrine was that Congress might pass a law requiring records to be kept for informative and incriminatory purposes. Such records, "required to be kept by law," were then assimilated into the domain of public information and their produc. tion might be compelled without violating the privilege against self-incrimination. 335 U.S. at 15-19. The irony of this position is manifest. If, as the majority also asscrted, oral testimony may not be compelled, the businessman who refuses ab initio to comply with a disclosure law by not keeping records has a greater constitutional protection than the "law-abiding" merchant who might unknowingly have violated the law, but kept the required records. See Maguire $\$ 2.09$, at $104 \&$ n.24.

${ }^{48}$ For a discussion which accommodates the "personal-impersonal" test of the White case to Shapiro on the ground that the latter reflects the exercise of Congress' war power see Note, The Constitutional Rights of Associations to Assert the Privilege Against Self-Incrimination, I12 U. PA. L. REv. 394, 398.402 (1964). The same commentator would apply only the White test in determining fifth amendment applicability. Id. at 402. Since Shapiro's apparent elimination of the White test, however, lower courts have treated the latter decision in a rather eavalier manner to support or deny the production of "personal" business records such as those of a partnership. Compare United States v. Fulcher, 229 F. Supp. 456, 458 (D. Md. 1964), Unitcd States v. Onassis, I33 F. Supp. 327, 33I-35 (S.D.N.Y. 1955), and United States v. Silverstein, 3I4 F.2d 789 (2d Cir.), cert. denied, 374 U.S. 807 (1963), with United States v. Cogan, 257 F. Supp. I70 (S.D.N.Y. I966).

48 395 U.S. at I5. The foundation for acceptance of the informational technique had been laid by early bankruptcy cases wherein the Court had refused to permit inculpatory private business records surrendered to the referee under the bankruptcy laws to be protected by invocation of the fifth amendment. See, e.g., McCarthy v. Arndstein, 266 U.S. 34, 4 I (1924); cf. Perlman v. United States, 247 U.S. 7, 13-15 (1918).

so 335 U.S. at 15; see 8 WiGMORE $\$ 2259$ c, at 367 \& n.15; Meltzer, supra note 4 , at 712. The Court indicated that this congressional power to require records for the enforcement of regulations was subject to due process limitations: "It may be assumed at the outset that there are limits which the Government cannot constitutionally exceed in requiring the keeping of records which may be inspected by an administrative agency and may be used in prosecuting statutory violations committed by the record-keeper limself. But no serious misgiving that these bounds have been overstepped would appear to be evoked when there is a sufficient relation between the activity sought to be regulated and the public concern so that the Government can constitutionally regulate or forbid the basic activity concerned, and can constitutionally require the keeping of particular records, subject to inspection by the Administrator." 335 U.S. at 32 . See note 82 infra. United States v. Morton Salt Co., 338 U.S. 632 (1950), however, indicated that administrative fisling expeditions and general surveillance of organizational records were proper simply for purposes of general supervision. See id. at 652 .

${ }^{52}$ Curcio v. United States, 354 U.S. 118 (1957). See generally Fraser, supra note 25; Meltzer, supra note 4. 
pelled to testify orally as to the contents or whereabouts of organizational records. ${ }^{52}$ The recent expansion of the privilege to include not only oral statements but all "testimonially communicative acts" argues for a reconsideration of compelled organizational disclosure which is incriminatory to an individual member. ${ }^{53}$

\section{The "Organization MaN" and the First Amendment}

Review of regulatory schemes implemented by informational disclosing was also dictated by the Supreme Court's increased emphasis on the right of anonymity ${ }^{54}$ inherent in the newly-emphasized first amendment freedom of association. ${ }^{55}$ Constitutional impediments

00354 U.S. at 123-25. Earlier cases had asserted that officers retained an oral privilege with respect to corporate records. See Shapiro v. United States, 335 U.S. 1, 27 (1948); Wilson v. United States, 221 U.S. 361, 385 (1911). But see United States v. Bryan, 339 U.S. 323, 332 (1950) (dictum); Pulford v. United States, 155 F.2d 944, 947 (6th Cir. 1946) (officer may be required to authenticate records); United States v. Austin-Bagley Corp., 31 F.2d 229 (2d Cir.), cert. denied, 279 U.S. 863 (1929) (same). See generally Handler, The Constitutionality of Investigations by the Federal Trade Commission (pts. I-II), 28 ColuM. L. REv. 708, 905 (1928). The Court's willingness to grant an oral privilege to corporate officers may have been related to the thenprevailing concept of the fifth amendment as an absolute prohibition against compelled testimony "from the accused's own mouth." See, e.g., Shapiro v. United States, supra at 27. However, the Court's precise decision was unclear. It may have been that the privilege was granted because merely divulging the location of the records would have involved the accused in a crime. On the other hand, the reasoning may have been that no oral testimony could be compelled from an individual officer. See 354 U.S. at 125, 127 \& n.6. Compare United States v. Austin-Bagley Corp., supra at 253-54, with Shapiro v. United States, supra at 27, and United States v. Daisart Sportswear, Inc., 169 F.2d 856, 861-62 (2d Cir. 1948), tev'd on other grounds sub nom. Smith v. United States, 337 U.S. 137 (1949). In either event, however, the "oral" exception remains anomalous to the extent that an officer may be required to write in a report that which he cannot be forced to speak orally. See Note, 68 Harv. L. REv. 340, 341-42 (1954). Compare Gilbert v. California, 388 U.S. 294 (1967), and Schmerber v. California, 384 U.S. 757 (1966), with Curcio v. United States, 354 U.S. 118 (1957). A possible explanation of the oral privilege exception could be that if an accused were compelled to testify orally, the prosecuting authorities would gain information "personal" to the accused and not "corporate" information. Cf. Hale v. Henkel, 201 U.S. 43, 70 (1906) (dictum). However, this explanation fails to resolve the anomoly because a corporate officer may reveal "personal" information in filling out a regulatory report.

${ }^{83}$ Under the standard enunciated in Schmerber, the "testimonial act" protection of the fifth amendment extends only to the individual asserting the privilege and not to invocation of the privilege on behalf of another party. See Schmerber v. California, 384 U.S. 757, 761 n.5 (1966); Note, 1967 DukE L.J. 366, 380 \& n.90.

os See Shelton v. Tucker, 364 U.S. 479 (1960); Talley v. California, 362 U.S. 60 (1960); Bates v. Little Rock, 361 U.S. 516 (1960); NAACP v. Alabama ex rel. Patterson, 357 U.S 449 (1958); Douglas, supra note 25, at 1376-83; Emerson, Freedom of Association and Freedom of Expression, 74 YALE L.J. 1 (1964); Comment, The Constitutional Right to Anonymity: Free Speech, Disclosure and the Devil, 70 YALE L.J. 1084, 10971103 (1961).

${ }^{5}$ See Douglas, supra note 25; Emerson, supra note 54; Rice, supra note 25; Note, 46 VA. L. REv. 730 (1960). 
to requiring group disclosures having repressive effects on membership were emphasized by attempts to regulate two such "first amendment" organizations, the Communist Party and the NAACP. The NAACP's refusal to produce its membership lists in contravention of Alabama's right to control foreign corporations resulted in NAACP v. Albama ex rel. Patterson. ${ }^{56}$ Recognizing the Association's privilege to protect its adherents from public retribution which would operate to discourage membership, ${ }^{57}$ the Court held that the governmental interest served by the Alabama foreign corporation statute was insufficient to justify the deterrent effects on the members' "right to pursue their lawful private interests and to associate freely with others ....."58

Conversely, in Communist Party of the United States v. SACB (1961), ${ }^{59}$ the Court weighed the Party's associational rights against congressional conclusions that the organization represented a threat to national survival, finding in the latter a "state interest" sufficient to debilitate the first amendment. ${ }^{60}$ However, as a result of the Court's failure to pass upon the Party's fifth amendment claim, ${ }^{01}$ the latter refused to disclose the demanded information ${ }^{02}$ within the time prescribed by the Subversive Activities Control Act. Consequently, responsibility for disclosure of Party affiliation devolved upon the individual Party member. ${ }^{63}$ Although both first and fifth amendment challenges were made to this mandate, the Court, in Albertson v. $S A C B,{ }^{64}$ reached only the latter issue. ${ }^{65}$ Acknowledging

so 357 U.S. 449 (1958).

${ }^{87}$ The Court spoke of the NAACP as the "proper representative of its membership." Thus it seems that the first amendment was not being extended to the organization but rather for the organization parens membership. See id. at 458.59.

${ }^{58} 357$ U.S. at 466; see Louisiana ex rel. Gremillion v. NAACP, 366 U.S. 293 (1961); cf. Gibson v. Florida Legislative Investigation Committee, 372 U.S. 539 (1963); Shelton v. Tucker, 364 U.S. 479 (1960).

so 367 U.S. 1 (1961).

60 $1 d$. at $93-97$.

or See note 13 supra and accompanying text.

${ }^{62}$ Under $\$ 27$ (a) of the Subversive Activities Control Act, the Party was to register and file the disclosure statement within 30 days after the order became final. 50 U.S.C. $\$ 786$ (a) (1964). See note 10 supra.

os Subversive Activities Control Act $\$ 8,50$ U.S.C. $\$ 787$ (1964). If the Party failed to register as required, the individual memhers came under an obligation pursuant to $\S 8$ of the Act to register themselves as members of that organization. If the members did not voluntarily register, the Attorney General, under $\$ 13$ of the Act, 50 U.S.C. $\$ 792$ (a) (1964), was to petition the Board for a registration order directed toward those individuals whom he had reason to believe were Party members.

84382 U.S. 70 (1965).

${ }^{65}$ Id. at $73,74 \& \mathrm{c}$.6. 
that self-incrimination was the inevitable result, the Court ruled that a Party adherent might not be criminally punished for failure to register information leading to his punishment under other statutory schemes. ${ }^{66}$

\section{Communist Party v. United States (1967)}

Arising after Albertson, the instant case was an appeal from the Party's second conviction for failure to register and disclose its membership lists. ${ }^{67}$ The issue presented on appeal was essentially whether the Government could accomplish by means of associational registration and disclosure that incrimination which Albertson made unconstitutional to require of individual members. ${ }^{68}$ Although a first amendment violation was argued, ${ }^{69}$ the circuit court considered first amendment rights only within the content of a derogation of the fifth amendment privilege against self-incrimination. Distinguishing "first amendment" associations from those which might be termed "economic action" organizations, the court indicated that only the former were protected from incriminatory disclosures. ${ }^{70}$ "Economic action" groups were not entitled to the privilege because "the public interest in the disclosure of the particular entity's affairs is deemed to be paramount ...."t1

${ }^{\circ}$ Id. at 78. The Albertson Court also held that individual members' claims of privilege were ripe for adjudication because their claim of privilege had been rejected by the Justice Department, thereby placing the petitioners in the position of subjecting themselves to incrimination or punishment for non-registration. Thus, unlike the Party's claim in Communist Party of the United States v. SACB, 367 U.S. I (1961), Albertson represeuted an example of immediate punishment without a hearing on the merits of the claimant's fifth amendment invocation. See 382 U.S. at 74-77; note 13 supra and accompanying text.

${ }^{\text {or }}$ See Communist Party of the United States v. United States, 384 F.2d 957 (D.C. Cir. 1967).

${ }^{\circ}$ Id. at 962. As characterized by the court, the issue was "whether, because of its impact on the Party membership the weapon of compelled disclosure can, consistently with the Fifth Amendment, be trained upon appellant." Id. at 960.

'0 See Brief for Appellant at 31. The Party's first amendment argument was that requiring registration as a "communist action" organization according to the Board's determination violated the first amendment in demanding that the Party repeat "a declaration which is contrary to appellant's belief and is self-defamatory as well as purposeless." Id. See generally Meltzer, Required Records, The McCarran Act, and the Privilege Against Self-Inerimination, 18 U. CHI. L. REv. 687, 721-22 (1951). The court's only allusion to this argument was that "so long as the self-incrimination clause of the Fifth Amendment endures, activity may be made criminal, but the actor cannot be compelled to characterize it as sucl and to disclose it." 384 F.2d at 962 (emphasis added).

to See 384 F.2d at 963.64 n.9, 964.65.

71 Id. at 965 . 
In resolving the inconsistencies between Albertson's mandate for an individual privilege and precedent refusing the privilege to organizations and their officers, the circuit court utilized a bifurcated theoretical/practical approach. ${ }^{72}$ The theoretical determination of fifth amendment applicability was based upon asserted distinctions between "first amendment" and "economic action" organizations. ${ }^{73}$ The practical rationale, however, allowed the Party to invoke the privilege because the legislative scheme could not possibly be effectuated without violating the Albertson rule against individual disclosure and self-incrimination. ${ }^{74}$

Pursuing its theoretical justification, the majority attempted to establish a privilege against self-incrimination on behalf of the Party itself. Assuming that either outlawry or organizational disclosure

\footnotetext{
${ }^{72}$ See id. at 964. Compare id. at 961-63, with id. at 966-67.

73 See $i d$. at 962-64 nn. 7-9.

"See id. at 965-67. The court noted that one of the grounds for the Albertson decision was that there the "self-incrimination claims were "not asserted in an essentially noncriminal and regulatory area of inquiry, but against an inquiry in an arca pcrmeated with criminal statutes where response to any of the ... questions in context might involve the petitioners in the admission of a crucial element of a crime." Id. at 960 (quoting from Albertson v. SACB, 382 U.S. 70, 79 (1965)). In the opinion of the majority, this distinction placed appellant's fifth amendment claim in a far different position from that of corporate officers who are required to fill out regulatory forms. See 384 F.2d at 965 . However, such an argument is too narrow, for it predicates fifth amendment applicability only upon incrimination by revelation of status, rather than the entire spectrum of "testimonial" activities which may be required of the individual on behalf of the entity. See Note, The Constitutional Rights of Associations to Assert the Privilege Against Self-Incrimination, 112 U. PA. L. REv. 394, 405-06. See also Affeldt, Group Sanctions and Sections $8(b)(7)$ and $8(b)(4)$ : An Integrated Approach to Labor Law, 54 Gro. L.J. 55, 65-73 (1965). But see Communist Party of the United States v. SACB, 223 F.2d 531, 578-80 (D.C. Cir. 1954) (Bazelon, J., dissenting), rev'd, 351 U.S. 115 (1956). Further, even if the Albertson rationale were valid within the context of organizational disclosure, such reasoning would operate to crcate a privilege for corporate officers also, for the "regulation" of economic groups is generally achieved through criminal sanctions: "Perfectly lawful in itself and, indecd, permitted only to exist by the favor of the Jaw, a business corporation may in operation fall afoul of a multitude of public purposes embodied in regulatory laws with criminal sanctions." 384 F.2d at 963 n.9 (emphasis added). But see Morgan, The Privilegc Against Self-Incrimination, 34 MiNN. L. REv. 1, 37-38 (1949).

Finally, the court admits that resistance to organizational disclosure has rcsulted in the punishment of individuals not the organization: "The doctrine that corporations and associations have no privilege has largely been enunciated in cases where an individual was sought to be criminally punished for refusing to produce records belonging to the entity and kept in the course of its business." 384 F.2d at 962 (emphasis added). See notes 120-21 infra and accompanying text. The above factors, ignored by the court, simply point up the necessity for granting the privilege against self-incrimination to officers of economic entities since they are compelled to testimonial acts which result in self-incrimination, or alternatively punishment for contempt or perjury. See also Murphy v. Waterfront Comm'n, 378 U.S. 52, 55 (1964).
} 
was proper as a discrete method of regulation, ${ }^{75}$ the court held that a conjunctive application was constitutionally invalid because criminal sanctions had been attached to Party membership. ${ }^{76}$ The unconstitutionality of such an approach, however, was found to avail appellant little if the Party remained unable to invoke an associational privilege against self-incrimination. ${ }^{\mathbf{7 7}}$ Consequently, in order to establish the economic first amendment organization distinction, it became necessary for the majority to distinguish precedent denying the fifth amendment to organizations and their officers. Borrowing the basic rationale of that precedent, the court first asserted that the corporate disclosure rule rested upon the public's interest in "continuing access" to the records of regulated groups. ${ }^{78}$ Yet the majority failed to state why this point was not equally applicable to the records of "subversive" organizations, for the public interest in securing disclosure from "economic action" groups is no more compelling than securing information from a group which threatens national survival. Information necessary to survival would seem essential to the existence of an economy apart from its regulation. Moreover, unless the commerce clause is a stronger basis for legislative action than the "inherent" power of national survival, there is no constitutional distinction which justifies incriminatory disclosure of economic entities but not of subversive entities as well. Also, the public interest concept rationalizes only the organizational disclosure, failing to accommodate or explain the resultant incrimination of individuals attached to the economic entity. ${ }^{79}$ Finally, utilizing the public in-

\footnotetext{
${ }^{75} 384$ F.2d at 961-62. The court stated that the Party had itself been subjected "in substance" to an outlawry which thereby vitiated the constitutionality of the disclosure scheme. See id. at 960 . However, the only statute which purports to outlaw the Party, Communist Control Act of 1954, 50 U.S.C. $\$ \$ 841-44$ (1964), has, as noted by the circuit court, been read to treat the Party only as a "currently erring" political organization, not one devoid of all constitutional rights. See 384 F.2d at 965-66 n.11. Further, that act may be read as imposing no penalties whatsoever on the Party itself. Sce note 105 infra. But see Communist Party of the United States v. United States, 33I F.2d 807, 812 (D.C. Cir. 1963) ("The legislative array facing the Party virtually makes it a criminal conspiracy per se.").

${ }^{70} 384$ F.2d at 960,961-62. The circuit court in the instant case affirmed the holding of Communist Party of the United States v. United States, 331 F.2d 807, 813 n.10 (1963), that the immunity provisions for those registering the Party were inadequate because they prevented only the fact of registration from being introduced in a subsequent trial -not information garnered from the registration disclosures. See Communist Party of the United States v. SACB, 223 F.2d 531, 578 (D.C. Cir. 1955) (Bazelon, J., dissenting), rev², 351 U.S. 115 (1956); Meltzer, supra note 69, at 724.

77384 F.2d at 962.

${ }^{78}$ Id. at $962-63$ \& $\mathrm{n.7}$; see id. at 964-65.

70 In utilizing the "public interest" concept, neither commentators nor courts have
} 
terest to support economic organizational disclosures provides no constitutional support for permitting revelations of criminal violations in the economic area while disapproving those in the security sphere.

Although failing to resolve these inadequacies of the "public interest" rationale, the circuit court did note that justifying compelled disclosure by economic organizations by "expediency" doctrines begged the "essential question" of the constitutionality of concomitant restraints upon an individual's privilege against self-incrimination. ${ }^{80}$ Nevertheless, the only solution advanced was that an ad hoc balancing test of governmental versus associational or individual interests should be utilized to determine fifth amendment applicability in economic disclosure cases. ${ }^{81}$ The court, however, proffered neither relevant criteria nor a constitutional basis by which these interests might be distinguished from or paralleled to those unarticulated interests mandating self-incriminatory protection for individuals affected by the disclosure of first amendment organizations. Moreover, the balancing approach leaves the "economic action" individual in legalized limbo: if he invokes the privilege and is not within its protection, he may suffer a contempt conviction or criminal punishment; if he discloses and is convicted, he may learn that the evidence need never have been revealed. ${ }^{82}$

yet explained why there is a greater public interest in requiring reports revealing economic violations than in requiring all murderers or thieves to register their activities with an agency for the regulation of crime. But see Mansfield, The Albertson Case: Conflict Between the Privilege Against Self-Incrimination and the Government's Need for Information, 1966 SUP. CT. REv. 103, 146-64. "Public interest" in the control of syndicated crime is certainly as great as punishing a giant corporation for violations of the antitrust laws. The only explanation secms to lie in expedicncy; i.e., the impossibility of an "underground" public corporation renders it more vulnerable to governmental control.

so 384 F.2d at 963 n.8, quoting Meltzer, supra note 69, at 701-06; see Mansfield, supra note 79. The lack of constitutional rationale was noted by dissenters to the organizational disclosure doctrine as early as Hale v. Henkel, 201 U.S. 43, 88 (1906) (Brewer, J., dissenting), and Wilson v. United States, 221 U.S. 361, 390-91 (1911) (McKenna, J., dissenting). Cf. Shapiro v. United States, 335 U.S. 1, 51 (1948) (Frankfurter, J., dissenting).

81 See 384 F.2d at 963 n.8.

82 For a discussion of federal immunity statutes which mitigate the difficulties of determining the occasion for proper invocation of the fifth amendment sec Comment, The Federal Witness Immunity Acts in Theory and Practice: Treading the Constitutional Tightrope, 72 YALE L.J. 1568 (1963). The difficult task of knowing when to assert the privilege without incurring a contempt sentence is not resolved by the solutions offered by scveral commentators. For example, Meltzer has suggested that fifth amendment applicability should be determined by weighing the governmental need for information, violations of individual privacy, and the existence of a purpose other than the detection of criminal violations. Mcltzer, supra note 69, at 715. Mansfield 
Despite an attempt to avoid "begging" the same question of fifth amendment limitations with respect to "first amendment groups," the court nevertheless did no more than imply that such a connotation ipso facto created a constitutional enclave within the compelled disclosure doctrine. ${ }^{83}$ The majority grounded withholding the privilege from economic groups upon the conclusion that "[o]ne who invests in a corporation or joins a labor union commits himself to the collective pursuit of economic ends ...." for which the unit exists. ${ }^{84}$ The validity of determining individual self-incriminatory protection according to a classification of strictly group purposes may be readily questioned. It is apparent, for example, that many first amendment groups, such as the NAACP, may have economic as well as social objectives $^{85}$ and that the organizational unit is the vehicle intended

would agree with this basic approach, but would place additional factors on the balancing scale, including the importance of the governmental objective; the requirement that disclosure be utilized to accomplish this end; whether disclosure is "conditioned upon engaging in an activity deemed basic to freedom; and whether the disclosed information would be utilized in a criminal proceeding." Mansfield, supra note 79, at 160. But see 8 WIGMORE $\S 2259 \mathrm{c}$, at $366-67$ (indicating that such factors are relevant only to due process limitations on the scope of regulation, not fifth amendment applicability). Although the "balancing" solutions have appeal, they fail adequately to account for those situations where the individual is the "confessing instrument" of his own conviction in the reporting or production of associational information. See Note, The Constitutional Rights of Associations to Assert the Privilege Against Self-Incrimination, 112 U. PA. L. REv. 394, 406 (1964). See notes 112-17 infra and accompanying text.

McNaughton would require only that the Government show prior knowledge that such incriminatory information existed before allowing the abolition of a claim of privilege. See McNaughton, The Privilege Against Self-Incrimination, 51 J. CRIM. L.C. \& P.S. 138, 145-46 \& n.37, 153-54 (1960). Yet another commentator has suggested that the privilege is applicable only in terms of "freedom from compelled disclosure of private information." Note, 65 Colum. L. REv. 681, 693-94 (1965). Thus, the "compulsion" aspect of self-incrimination would become relevant only if records were required to be kept which would not "ordinarily come into existence." Id. at 693 . Concomitantly, personal privacy would be invaded only in the same circumstances, for those records which are ordinarily kept would not be a reflection of matters normally considered personal or private by the associational individual. Id. at 693-95. This solution, however, seems particularly vulnerable to criticism for it results in unequal protection against self-incrimination for individuals depending upon habits and willingness to flout the law. For example, if the defendant normally recorded all of his activities in the ordinary course of business, he would lose the privilege; yet the businessman who did not record any information, or only the most basic material, would be protected from such disclosure and might equally escape punishment for failure to report at all.

${ }^{83}$ See 384 F.2d at 964-65. See note 107 infra and accompanying text.

84 384 F.2d at 963 n.9. See generally Affeldt, supra note 74 .

${ }^{85}$ For a general discussion of the drive for Negro advancement in economic areas see Batchelder, Economic Forces Serving the Ends of Negro Protest, 357 Annals of THE AMrer. AGAD. OF Polit. AND Soc. ScI. 80 (1965), and Morsell, The National Association 
to accomplish these purposes. Yet it seems clear from the court's approach that fifth amendment protections would be granted to individuals within such a group. The "group purpose" concept, in failing to consider whether the individual's relationship to the group is inculpatory, does not seem to be a valid criterion for distinguishing fifth amendment applicability. ${ }^{86}$

The circuit court, however, advanced a second distinguishing factor, positing that the first amendment encompasses the personal right to associate with those of similar beliefs "whereas the right to form a corporation or labor union is nowhere guaranteed in terms by the constitution." 87 Failing to mention that the right to join a union has been held to be constitutionally based, ${ }^{88}$ the majority also did not explain why a positive grant of first amendment rights was correlative to a right to invoke the privilege against self-incrimination. Thus, while it is clear that the right to promote one's interest through a particular economic form is not expressly guaranteed by the Constitution, ${ }^{89}$ it seems equally apparent that an absolute prohibition of association for the accomplishment of permissible economic ends would not comport with constitutional considerations. ${ }^{90}$

for the Advancement of Colored People and Its Strategy, 357 ANNALS OF THE AMER. Acad. OF Polit. AND Soc. Scr. 97 (1965).

${ }^{80}$ But cf. McNaughton, supra note 82, at 145-46 \& $\mathrm{n} .37$ (implying that the "first amendment" appellation may be sufficient to allow invocation of the privilege against self-incrimination by group or associated individuals).

87 384 F.2d at 964 n.9.

88 See Rice, The Constitutional Right of Association, 16 Hastincs L.J. 491, 493-99 (1965); note 90 infra. See generally Affeldt, supra note 74.

80 Various first amendment cases involviug individual rights within an employmcntdisclosure context have seemingly been partially predicated upon a privilege to work without giving up the protection of the fifth amendment. See Slochower v. Board, 350 U.S. 551 (1956). Compare Bates v. Little Rock, 361 U.S. 516 (1960), with Talley v. California, 362 U.S. 60 (1960), and Shelton v. Tucker, 364 U.S. 479 (1960). See also the dissenting opinions in Uphaus v. Wyman, 360 U.S. 72, 82 (1959), and Barenblatt v. United States, 360 U.S. 109, 134 (1959).

${ }^{\circ B}$ There are negative implications of a constitutional "right to work." For example, in McAuliffe v. New Bedford, 155 Mass. 216, 220, 29 N.E. 517, 517-18 (1892), Mr. Justice Holmes stated that "there are few employments . . . in which the servant does not agree to suspend his constitutional right of free speech, as well as of idleness, by the implied terms of his contract."

The primary support for an argument that the economic role is constitutionally protected, however, is derived from dicta in the Supreme Court decisions upholding the "riglit to work" laws of various states. See AFL v. American Sash \& Door Co., 335 U.S. 538, 540 (1949); Lincoln Federal Labor Union v. Northwestern Iron \& Metal Co., 335 U.S. 525, 530-31, 534-37 (1949). The right to join a labor union, an economic activity organization, is also considered to have constitutional stature. See Lincoln Federal Labor Union v. Northwestern Iron \& Metal Co., supra; Wallace Corp. v. NLRB, 323 U.S. 248 (1942). Moreover, as it has been held that there is a constitutional right 
The court's approach implies that the economic role of the individual in a group status is somehow less worthy of fifth amendment safeguards than spiritual or political roles.9 Although emphasizing the personal implications of a first amendment role, such as the promulgation of political or religious beliefs, ${ }^{92}$ the majority failed to distill these characteristics into a constitutional basis distinguishing invocation of the fifth amendment only by first amendment groups or officers. Thus, the court necessarily conceded that the "personalimpersonal" test enunciated in White ${ }^{93}$ was not helpful in determining applicability of the fifth anendment in a concrete case..$^{94}$

Admitting that its theoretical "personal" first amendment approach had proved too "elusive," 95 the majority ultimately determined the privilege to be available by a practical approach based upon the observation that all associational entities acted only through "human instrumentalities." As Although largely disregarding the

to engage in interstate commerce, a necessary inference is that individuals must be able to work in interstate commerce. See Garrity v. New Jersey, 385 U.S. 493, 500 (1967), citing Western Union v. Kansas, 216 U.S. I (1910). But see United States v. Morton Salt Co., 338 U.S. 632, 652 (1951) ("The Federal Government allows [corporations] the privilege of engaging in interstate commerce.") (emphasis added). Recently, in United States v. Robel, 389 U.S. 258 (1967), the Supreme Court ruled unconstitutional $\$ 5$ (a) (1) (D) of the Subversive Activities Control Act of 1950, 50 U.S.C. $\$ 784$ (a) (1) (D) (1964). In the opinion of the Court, it was a violation of the first amendment. freedom of association to outlaw employment in a defense facility on the basis of "mere" membership in the Communist Party. Moreover, the Court approved the language of Greene v. McElroy, 360 U.S. 474, 492 (1959), that "the right to hold specific private employment and to follow a chosen profession free from unreasonable governmental interference comes within the 'liberty' and 'property' concepts of the fifth amendment." 389 U.S. at $265 \&$ n.11.

ax Compare Lincoln Federal Labor Union v. Northwestern Iron \& Metal Co., 335 U.S. 525 (1949), with NAACP v. Alabama ex rel. Patterson, 357 U.S. 449 (1958), and Louisiana ex rel. Gremillion v. NAACP, 366 U.S. 293 (1961). See also Spevack v. Klein, 385 U.S. 511 (1967); Garrity v. New Jersey, 385 U.S. 493 (1967).

02384 F.2d at $963-64$ n.9.

os 322 U.S. 694 (1944). See notes 40-45 supra and accompanying text.

$04384 \mathrm{~F} .2 \mathrm{~d}$ at $964-65$.

${ }^{05} I d$. at 964. One commentator who applied the White test to the issue of Communist Party disclosure concluded that a world-wide conspiracy was so "impersonal" as to mandidate debilitation of fifth amendment protections. See Note, The Constitutional Rights of Associations to Assert the Privilege Against Self-Incrimination, 112 U. PA. L. REv. 394, 414-16 (1964).

oo 384 F.2d at 965 . In introducing the practical phase of the opinion, the court seemingly implied that at least some business corporations and unions might also claim the privilege: "Short of trying in the abstract, to sort out associations for whom the privilege has meaning from those for whom it does not, it is useful to recall the reality which underlies them all. Although the law has made room for the concept of an artificial entity which, for some purposes at least, has a life separate and distinct from the individuals who comprise it, it remains the fact that no such entity can act other than through human instrumentalities." Id. at 964-65. However, the unprotected 
plight of the incriminated individual in an economic context, ${ }^{07}$ the court did recognize the self-inculpatory results of a disclosure scheme directed toward a first amendment group. ${ }^{88}$ The majority noted that under Albertson the privilege against self-incrimination shielded an individual from the compulsory inculpatory disclosure of Party affiliation.99 Because that organization's required records could be obtained only from such protected members, the order commanding the Party to disclose could not be implemented. ${ }^{100}$ Therefore, the regulations allowing disclosure of the requested information through an "agent" or "other person" provided no protection against selfincrimination since that individual could be required to disclose and thus incrimmate his source. Consequently, the court concluded that where crimmal sanctions are attached to participation in a first amendment organization, the fifth amendment prevents compulsory disclosures by either the organization or its members. ${ }^{101}$

Despite this dualized theoretical/practical approach to fifth amendment applicability, the court failed to present a coherent rationale accounting for the differing constitutional implications of economic and first amendment group disclosures with respect to the incriminated individual. Moreover, to the extent that the first amendment group exception does have a constitutional validity, the distinction was never related to the "personal-impersonal" standard of privilege enunciated in White. ${ }^{102}$

status of the economic entity, and thus its officers, was cursorily dismissed on the basis of the "public interest" concept. Id. at 965.

${ }^{87}$ See id. at $965,967$.

${ }^{88} I d$. at 965,968 . See notes 78-82 supra and accompanying text.

${ }^{80}$ Id. at 965 .

${ }^{100}$ Id. at 967. The circuit court phrased the "impossibility" of carrying out group disclosure through protected members in the following terms: "To the lay observer equipped only with a sure sense of logic and unconfused by the legal lore of the assertedly personal nature of the privilege this might suggest that the Act, like King Canute, vainly commands the impossible; and that the legislative scheme has a flavor of irrationality in a due process sense. But this condition of ineffectiveness to cn. compass the criminal punishment of appellant for something it lacks the means to accomplish derives in the last analysis from the Fifth Amendment's privilege against self-incrimination." Id, at 965. For a discussion of the "impossibility" argument in terms of unconstitutional conditions see generally Halc, Unconstitutional Conditions and Constitutional Rights, 35 CoLUM. L. REv. 321 (1935); Merrill, Unconstitutional Conditions, 77 U. PA. L. REv. 879 (1929); and Note, 38 IND. L.J. 520 (1953).

${ }^{101}$ See 384 F.2d at 967 . The court implied, at various times, that the "theoretical" and "practical" approaches were equivalents; that if an individual had a fifth amend. ment privilege with respect to a first amendment group, the organization also had a privilege against self-incrimination. See id. at 965,967 .

102 United States v. White, 322 U.S. 694 (1944). See note 43 infra and accompanying text. 
Utilization of a first amendment test of fifth amendment applicability required a delineation of both the scope of the privilege and the precise posture in which the fifth amendment was asserted by the Party. The privilege is personal in nature, protecting against "testimonial compulsion" which results in self-incrimination of the person asserting the fifth amendment. ${ }^{103}$ As invoked by the Party, however, the privilege was meant to protect the membership against the inculpatory results of compelled organizational disclosure. ${ }^{104}$ The only punishment attaching to the Party as an entity resulted from nondisclosure-not disclosure. ${ }^{105}$ Thus, in asserting the privilege, the Party's position paralleled that of the association in NAACP v. Alabama ex rel. Patterson: ${ }^{106}$ the entity desired to raise a constitutional right of its members in order that the organization itself might escape punishment for nondisclosure. Clearly, the Party's claim was vicarious, derived from the privilege of its adherents. Therefore, the circuit court's statement that the privilege stands between the Party and the punishment sought to be imposed upon it for nondisclosure pertains only to the relation between the incriminatory effect of the Party's disclosure upon its members and the fifth amend-

103 See Schmerber v. California, 384 U.S. 757, 760-65 (1966); Note, Supreme Court Delineates the Relationship Between the Fourth and Fifth Amendments, 1967 DukE L.J. 366, 380-81 \& n.90.

10، See Brief for Appellant at 17-25, Communist Party of the United States v. United States, 384 F.2d 957 (D.C. Cir. 1967).

${ }^{108}$ Congress, in passing the Communist Control Act of 1954, 50 U.S.C. $\$ \$ 841-44$ (1964), provided that "the Communist Party should be outlawed." Id. $\$ 841$. However, $\$ 2$ of that Act provided for no penalties against the Party, except that it should not be "entitled to any of the rights, privileges, and immunities attendant upon legal bodies created under the jurisdiction of the laws of the United States or any political subdivision thereof; and whatever rights, privileges and immunities have been granted ... are terminated ...." 50 U.S.C. $\$ 842$ (emphasis added). Arguably, the Act could be interpreted to mean that because the Party was not incorporated and therefore had not been created by the United States or any individual state, the 1954 Act deprived it of no rights and disclosure would have subjected it to no penalties or punishments. See note 75 supra.

The scope of the application of the Act seems to have been tested only once in the courts. In Communist Party of the United States v. Catherwood, 367 U.S. 389 (1961), the Supreme Court held that New York could not exclude the Party from that State's unemployment compensation system with the result that the petitioner would have to pay a higher federal tax rate, simply on the basis of the declaration in $\$ 2$ of the Act that the Party should be deprived of the rights, privileges and immunities granted by a political subdivision of the United States. 367 U.S. at 394, 395. The only other court which concerned itself with the meaning of the Act was hesitant in describing the scope of the provisions as taking away rights which Congress might constitutionally take away. See United States v. Silverman, 132 F. Supp. 820, 828-29 (D. Conn. 1955), rev'd, 248 F.2d 671 (2d Cir. 1957), cert. denied, 355 U.S. 942 (1958). 108357 U.S. 449 (1958). See note 57 supra and accompanying text. 
ment privilege held by them. The implication that a first amendment organization itself has a privilege whenever the punishment would be effectuated against the organization for a crime not in. culpatory to its adherents is dictum. ${ }^{107}$

Alabama ex rel. Patterson ${ }^{108}$ had made clear that an associational entity could assert its adherents' first amendment rights. By exercising their freedom of association, NAACP members had taken on the attributes of the organization-which thus became but a magnification of each individual member's beliefs. ${ }^{108}$ The group, then, was entitled to assert the first amendment rights of the membership because of the close "nexus" between the organization and members. ${ }^{110}$ On the other hand, in the instant case a first amendment group was asserting a constitutional right of its members other than the first amendment. Arguably, such vicarious protection is permissible whenever legislation or administrative action directed at the organization has the effect of diluting an individual's right to associational anonymity or the privilege against self-incrimination because the individual himself cannot assert the theory of such rights in a legal proceeding without, in reality, losing their protection. ${ }^{111}$ Thus, an individual who joins a first amendment group thereby "testifies" as to the beliefs promulgated by that organization.112 If association

${ }^{107}$ The court's strongest intimation of an organizational privilege per se was framed as an alternative statement of the practical and theoretical rationales: "The result is surely the same whether it be stated in terms of the availability of the privilege to appellant, because of its distinctive nature or whether it be said that it is a violation of the privilege concededly available to the individuals associated with appellant . . . ." 384 F.2d at 965; see id. at n.4; notes 100, 101 supra. Unitcd States v. White, 322 U.S. 694 (1944), had also implied that a privilege might exist on behalf of the organization itself. See note 43 supra and accompanying text. But see notes 103.06 supra and accompanying text.

208357 U.S. 449 (1958).

${ }^{100}$ While individual variations on the organizational theme must be recognized, nevertheless, with a voluntary organization, the individual may, and presumably will, leave the fold when the disparity between his belief and the group belief becomes too great. Mr. Justice Frankfurter early recognized the intimate relationship even between involuntary associations and their members: "A union is no more than a medium through which individuals are able to act together; union power was begotten of individual helplessness. But that power can come into being only when, and continues to exist only so long as, individual aims are seen to be shared in common with the other members of the group." AFL v. American Sash \& Door Co., 335 U.S. 538, 545 (1949) (Frankfurter, J., concurring). See generally Affeldt, supra note 74.

110357 U.S. at 459 .

111 See id.

112 Compare Schmerber v. California, 384 U.S. 757 (1966), with AFL v. American Sash \& Door Co., 335 U.S. 538, 545 (1949) (Frankfurter, J., concurring), and NAACP v. Alabama ex rel. Patterson, 357 U.S. 449 (1958). 
for the purpose of effectuating that belief is outlawed, the taint of criminality reaches the individual in his group status. Accordingly, the fifth amendment should protect against the associational inculpation of the earlier "testimonial" step taken by the individual in becoming a member.

It might be urged, however, that the fifth amendment prohibits only testimonial compulsion against the individual asserting the privilege and that the compulsion in the instant case was directed toward the organization rather than the members since the punishment for nondisclosure was a fine against the Party. ${ }^{113}$ However, Congress had determined that the Communist Party was dedicated to the violent overthrow of the Government and had made criminal individual membership in order to prevent effectuation of the Party's goals. ${ }^{114}$ Thus to be a member was, in terms of the Smith Act, to be one with the Party. ${ }^{115}$ Consequently, compulsion directed toward the association was compulsion against the individuals comprising that group. The Party, then, as a first amendment organization, should be entitled to assert the privilege against self-incrimination because the relationship between individual and group is such that the entity has no "life separate" from those who comprise it.116

If this group-individual congruity is accepted as the basis of the court's first amendment distinction, then the "personal-impersonal" test for fifth amendment applicability also becomes meaningful within the constitutional framework. As the individual becomes less "testimonially" involved with an entity,"117 his relationship to the organization is less "personal" in scope and the interaction of the two is molded less by group desire than individual necessity. Correlatively, the "testimony" of the entity becomes a feature separate from

${ }^{113}$ Such an argument would be based upon the theory that compulsion against $A$ to produce property incriminatory to $B$ is not compulsion against $B$. See note 6 supra. 114 See note 74 supra.

${ }^{215}$ Compare Albertson v. SACB, 382 U.S. 70 (1965), with Scales v. United States, 367 U.S. 203 (1961).

116384 F.2d at 964-65. See notes 15, 112 supra and accompanying text.

117 To the degree that an association represents a belief or emotional stance of an individual, the latter may be said to be "testimonially" involved or identified with the organization itself. See note 112 supra and accompanying text. However, as the associational purpose loses its characteristics as the fulfillment of personal beliefs and becomes a vehicle for remunerative gratification only, group and individual are no longer testimonially identical because the organization itself exists on a functional, not a personal, level. See note 109 supra. 
the "testimony" of its members. ${ }^{118}$ The individual, therefore, has no constitutionally recognized interest in having the organization invoke the "personal" privilege on his behalf.110 Yet the "compulsion" exerted against the organization may be effectuated in such a manner that the activities of the individuals through whom it must act become personally testimonial, ${ }^{120}$ as where an individual officer is forced to respond to a subpoena duces tecum of business or corporate records or to sign informational reports of incriminatory material. ${ }^{121}$ If the state may ignore individual incrimination because the records "belong" to the entity, or are "necessary" to its regulation, then administrative control of the organization becomes a conduit for the exercise of state compulsion against the individual. ${ }^{122}$ The economic organization's lack of privilege, there-

${ }^{118}$ See AFL v. American Sash \& Door Co., 335 U.S. 538, 545 (1949) (Frankfurter, J., concurring).

${ }_{110}$ Cf. Schmerber v. California, 384 U.S. 757, 760-65 (1966).

${ }^{120}$ Mansfield has suggested that a violation of the fifth amendment occurs if a reporting scheme is directed solely at the individual and entirely or predominately for the purpose of incrimination. See Mansfield, supra note 79, at 139.60. Meltzer, however, has stated that there is no historical justification for allowing invocation of the privilege simply because an allegedly general investigation is focused upon a particular individual. See Meltzer, supra note 69, at 694 . In his opinion, the duc process clause would be sufficient protection against reporting schemes aimed solely at criminal conviction. See id. at $727-28$.

${ }^{221}$ The permissible extent of compulsion against a group which necessitates incriminatory action in the mode of disclosure might well be determined by the extcnt to which the Government may act directly against the individual in disclosure or reporting situations. For example, from the dicta in United States v. Sullivan, 274 U.S. 259, 263 (1927), it would seem that an individual may be required to report in. come but claim the privilege against revealing its source if such information would lead to criminal conviction. Similarly, an individual could not be ordered, pursuant to compulsion against the organization, to disclose or register that which is criminally related to him personally. See Note, The Constitutional Rights of Associations to Assert the Privilege Against Self-Incrimination, 112 U. PA. L. Rev. 394, 405.06 (1964); cf. Marchetti v. United States, 36 U.S.L.W. 4143 (U.S. Jan. 29, 1968) (No. 2), overruling United States v. Kahriger, 345 U.S. 22 (1953), and Lewis v. United States, 348 U.S. 419 (1955) (registration and payment of gambling tax unconstitutional). See also United States ex rel. DeForte v. Mancusi, 379 F.2d 897 (2d Cir. 1967).

For discussion of the extent to which reporting statutes have been used against individuals see generally Mansfield supra note 79, and Note, Quasi Public Records and Self-Incrimination, 47 CoLum. L. Rev. 838 (1947).

${ }^{122}$ The Supreme Court has asserted that due process limitations exist with respect to the extent which the Government may utilize regulations for the purpose of securing information of criminal violations. See note 50 supra. Such statements, however, have not seemingly presented any effectual limitations on the omniscient exercise of governmental regulatory and disclosure powers. See, e.g., United States v. Morton Salt Co., 338 U.S. 632, 651-54 (1950). However, both Meltzer and Mansfield would utilize legislative purpose as a principal criterion for a balancing test to determine fifth amendment applicability. See note 82 supra. If it is conceded that the privilege is personal and therefore inapphicable to organizations, then a balancing test comprised of such due process considerations would seem appropriately applied to determine the 
fore, should be regarded simply as a neutral factor rather than a bridge by which the state may negate individual rights. Further, granting the full privilege to the individual associated with the economic entity is consistent with the "oral" testimony exception. ${ }^{123}$ Requiring an officer to produce in record form that information which he cannot be forced to produce orally seems to contravene rational constitutional doctrine. ${ }^{124}$ Thus, where an individual may become the confessing instrument of evidence which leads to his prosecution, the privilege against self-incrimination should bar compulsion to that end. ${ }^{125}$

constitutionality of requiring disclosure of the entity. However, this approach is not a viable protection for individuals who, in becoming involved with economic entities, do not agree to give up their privilege against self-incrimination for a "balanced" protection against the compulsory powers of the Government. See notes 6, 36 supra and accompanying text.

${ }^{123}$ Curcio v. United States, 354 U.S. 118 (1957). See notes 51-53 supra and accompanying text.

124 See Mansfield, supra note 79, at 136-38; Note, 68 HARv. L. REv. 340, $341-42$ (1954). $B u t$ see note 52 supra.

${ }^{125}$ If the full scope of the fifth amendment is held applicable to the "economic" individual, however, an answer must be given to the argument that effective governmental regulation of the economic entity is thereby rendered impossible. See generally Mansfield, supra note 79; Meltzer, supra note 69.

Where the Government seeks to control the operations of a one-man business, the relevant law might require the keeping of records but allow the businessman simply to claim the privilege with respect to items incriminatory to him personally. Placing the individual in a position where he may need to claim the privilege is not itself violative of the fifth amendment, and the Government would be advised of questionable activity. But see McNaughton, supra note 82, at 153-54; Communist Party of the United States v. SACB, 367 U.S. 1, 191 (1961) (Brennan, J., dissenting); note 13 supra. Proof of violation, however, would result from governmental investigation-not individual self-incrimination. See generally Schmerber v. California, 384 U.S. 757 (1966); Miranda v. Arizona, 384 U.S. 436 (1966). Moreover, in dealing with economic entities which are dependent upon public buying power, the Government might consider the utilization of disclosure in the manner of cease and desist orders isssued under the NLRB.

In determining effective means of controlling larger entities, while retaining the utility of disclosure, Congress and the administrative agencies might adopt the approach of the treble damages provisions of the Clayton Act. Increased punishment on the organization level would mitigate the necessity for rendering individual activity criminal, for the officer whose activities brought such sanctions upon the entity would no doubt find himself with a limited economic future. However, the most practical method of avoiding conflict between the privilege against self-incrimination and regulatory disclosure on the organizational level would be to require information to be disclosed through a non-incriminated agent who would not be permitted to disclose the name of those revealing the information to him. Moreover, members of the group would retain the privilege as a bulwark against signing incriminatory reports or producing such in response to a subpoena. See Note, The Constitutional Rights of Associations to Assert the Privilege Against Self-Incrimination, 112 U. PA. L. REv. 394, 405-06 (1964). Such methods would enable the Government to regulate economic activity, and retain compulsory disclosure-but without the self-incrimination of individuals affiliated with the group. 